9. Mel'nik N. Í. Teoretichní í metodichní zasadi profesíynoí pídgotovki doshkíl'nikh pedagogív u kraínakh Zakhídnoí Êvropi): dis. ... d-ra ped. nauk : spets. 13.00.04 "Teoríya í metodika profesíynoí osvíti"; 13.00.08 "Doshkíl'na pedagogíka" / Mel'nik Natalíya Ívanívna ; Umans'k. derzh. ped. un-t ím. Pavla Tichini. Uman', 2017. $622 \mathrm{~s}$.

10. Zevchenko T.M. Vikhovannya u shkolakh velikoí britaníi. URL: https://library.udpu.edu.ua/ library files/psuh pedagog probl silsk shkolu/11/visnuk 13.pdf

11. Doshkol'noye obrazovaniye ili Foundation Stage. URL: https://www.studentinfo.net/faq83foundation-stage

12. Brewer, M., Cattan, S., and Crawford, C. (2014) 'State support for early childhood education and care in England'. In Emmerson, C., Johnson, P. and Miller, H. (eds) IFS Green Budget 2014. London: Institute for Fiscal Studies. URL: www.ifs.org.uk/budgets/gb2014/gb2014 ch8.pdf.

13. Children and Families Act 2014 CHAPTER 6. URL: http://www.legislation.gov.uk/ukpga/ 2014/6/introduction/enacted

14. Local Government Regulation. 2018 URL: https://en.wikipedia.org/wiki/Local_Government_ Regulation

15. Childcare Act 2016 CHAPTER 5. URL: http://www.legislation.gov.uk/ukpga/2016/5/enacted

16. DfE strategy 2015-2020 World-class education and care March 2016 London- 29 p.

Одержано статтю: 22.10 .2019

Прийнято до друку: 13.11.2019

УДК 342.1 / 25 (477) (043.3)

DOI: $10.15330 /$ esu. 17.204-213

\author{
Андрій Танько, \\ кандидат юридичних наук, доцент, \\ Харківський національний \\ педагогічний університет \\ імені Г. С. Сковороди (м. Харків, Україна)
}

Andrii Tanko,

Candidate of law sciences $(\mathrm{PhD})$, Associate Professor

H. S. Skovoroda Kharkiv National

Pedagogical University (Kharkiv, Ukraine)

tanko0300@gmail.com

\title{
ЗАБЕЗПЕЧЕННЯ ПРАВ І СВОБОД ЛЮДИНИ: ГЕНЕЗА ТА СУЧАСНИЙ НОРМАТИВНО-ПРАВОВИЙ ДИСКУРС
}

\section{PROTECTION OF HUMAN RIGHTS AND FREEDOM: GENESIS AND MODERN LEGISLATIVE DISCOURSE}

У статті в контексті аналізу історичних передумов сучасного міжнародного та вітчизияного нормативного законодавства досліджено питания забезпечения прав і свобод людини як пріоритету функиіонування правової держави, висвітлено сутність провідних дефініцій “права” і “свободи”, ичо становлять орієнтир для розгортання демократичних прочесів в украйнському суспільстві. Проаналізовано суспільне призначения спечіальних державних інститутів, що здійснюють правоохоронну діяльність, зокрема, визначено провідну роль структур органів виутріиніх справ у забезпеченні прав та свобод людини. Доведено, що пріоритет прав і свобод людини є важливим орієнтиром для реалізачї правоохоронної функиії держави.

Ключові слова: права, свободи людини, особисті права $i$ свободи людини, демократичне суспільство, держава і громада, правова система, органи внутріиніх справ, правоохоронна діяльність.

In the context of the analysis of historical prerequisites, contemporary international and national normative legislation, scientific works of researchers, the issue of ensuring human rights and freedoms as a priority of the rule of law is revealed, the essence of the leading definitions of 
"law" and "freedom", which are the benchmarks for the deployment of the process, are highlighted. in Ukrainian society.

The purpose of the article is to reveal the essence of protection of human rights and freedoms as a priority for the functioning of the rule of law and its institutions, the basis for legal education and the promotion of the rule of law among the population.

The study found that the active integration into international law of international legal standards on human rights and freedoms began with the proclamation of independence and the adoption of a basic law - the Constitution of Ukraine, which secured the right of all categories of population to protect rights and freedoms, for the first time instead of a fragmentary set of rights and freedoms. The system of rights and freedoms was defined in all major spheres, civil, political, economic, social and cultural rights and freedoms of man and citizen were envisaged.

It is stated that today the category of "human rights and freedoms" is recognized in Ukraine, as well as in the world the normative and substantive basis for building relationships between the individual and the state, the society by which the limits of arbitrary actions and social opportunities of the person are regulated, institutional and regulatory and legal mechanisms of restrictive interaction between man and society.

The basic rights and freedoms laid down in the normative documents of Ukraine are analyzed: the Criminal Code, Laws of Ukraine "On Freedom of Movement and Free Choice of Residence in Ukraine", "On Prevention of Domestic Violence", "On Transplantation of Organs and Other Human Anatomical Materials", "Fundamentals of Ukrainian legislation on health care", etc.

The social purpose of special state institutes engaged in law enforcement activities is disclosed, in particular, the leading role of structures of law-enforcement bodies in ensuring human rights and freedoms is determined. It is proved that the priority of human rights and freedoms is an important guideline for the implementation of the state 's law enforcement function.

Key words: rights, human freedoms, personal rights and freedoms, democratic society, state and community, legal system, law enforcement agencies, law enforcement.

Актуальність проблеми. Проблема забезпечення й захисту прав і свобод людини та громадянина сьогодні $є$ гостро дискусійною як у політико-правовій й громадянсько-суспільній сферах, так і в наукових колах. Її вивчення в цілому та окремі iї аспекти стають стрижневими в соціально-філософських, соціологічних, соціально-психологічних і юридично-правових розвідках вчених, до них прикуто увагу цілих наукових підрозділів, засобів масової інформації, інтернет-джерел, різних соціальних груп та окремих громадян.

Українською державою здійснено низку суттєвих кроків, які свідчать про неухильний рух суспільства до встановлення правових основ життєдіяльності в будь-якій сфері життя, що грунтується на визнанні прав i свобод як найвищої людської цінності та $\epsilon$ пріоритетом у питаннях захисту людської гідності й недоторканості. Так, у Конституції України, положення якої зорієнтовані на світові стандарти правового захисту, пріоритетним обов'язком держави проголошується забезпечення прав і свобод людини (ст. 3). У Законі України "Про засади запобігання та протидію дискримінації в Україні" (06.09.2012 р.) зазначається, що державна політика спрямована на недопущення дискримінації щодо осіб незалежно від певних ознак (раса, колір шкіри, політичні, релігійні та інші переконання, стать, вік, інвалідність, етнічне та соціальне походження, громадянство, сімейний та майновий стан, місце проживання, мовні або інші ознаки); заохочення позитивних дій щодо таких категорій осіб; створення умов для своєчасного виявлення фактів дискримінації та забезпечення ефективного захисту осіб та груп осіб, які постраждали від дискримінації; виховання і пропаганду серед населення України 
поваги до осіб, які, на жаль, традиційно були об'єктом дискримінації в суспільстві; поширення просвітницької діяльності серед населення (ст. 7).

Аналіз останніх досліджень і публікацій. Упродовж останніх років вченими (В. Авер'янов, В. Андрейцев, А. Батіффоль, Р. Белламі, П. Бельди, Ю. Габермас, В. Горбатенко, А. Заєць, В. Кампо, Б. Кістяківський, М. Козюбра, О. Копиленко, А. Колодій, Г. Луф, В. Нерсесянц, Р. Павленко, В. Погорілко, П. Рабінович, К. Роде, С. Рябов, В. Селіванов, О. Скрипнюк, Ш. Смід, В. Тацій, Р. Ціппеліус, І. Шапіро, В. Шаповал, Ю. Шемшученко та ін.) проведено численні фундаментальні та прикладні дослідження, що складають грунтовну методологічну основу для осягнення сутності категорій "права" i "свободи", їх видів і форм, розуміння особливостей їх реалізації у різних суспільствах, , сприйняття цих соціальноправових феноменів як підгрунтя для розбудови демократичного, громадянського суспільства, нормативно-правової системи держави.

У контексті нашого дослідження особливо цінним $\epsilon$ сучасний доробок вітчизняних учених 3 питань верховенства прав і свобод людини, ролі держави та громади у іiї захисті (О. Бандурка, В. Бесчасний, О.Безпалова, Ю. Бітяк, І. Бородін, С. Благовісний, В. Букач, А. Васильєв, В. Вознюк, К. Волинка, А. Головін, О. Горова, Т. Дашо, О. Домбровська, С. Ківалов, А. Колодій, А. Комзюк, Я. Кондратьєв, В. Кравченко, О. Негодченко, Н. Нижник, О. Онишко, М. Панов, В. Погорілко, О. Скакун, В. Тихий, М. Хавронюк, О. Фрицький, Р. Шай та ін.).

Відзначимо, що аналіз досліджень вчених, нормативно-правових практик та реалій життя створює підстави для твердження, що, незважаючи на позитивні дії держави щодо встановлення рівності прав та недискримінації в суспільстві,

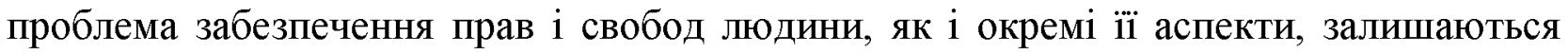
гостро актуальними в сучасному нормативно-правовому дискурсі.

Мета статті. На основі аналізу історичних передумов, сучасного міжнародного та вітчизняного нормативного законодавства, наукових праць дослідників розкрити сутність захисту прав і свобод людини як пріоритету функціонування правової держави та їі інституцій, основи для правової просвіти й пропаганди верховенства права серед населення.

Наукова новизна дослідження. У статті до фокусу дослідницької уваги потрапляють питання розробки механізмів захисту прав і свобод українського населення, висвітлення яких грунтується на глибокому аналізі основних дефініцій, пов'язаних 3 правовим захистом, що забезпечує створення методологічного підгрунтя для розробки i впровадження ефективних форм популяризації гуманістичних принципів, закладених у цих поняттях, серед фахівців і населення в аспекті збільшення можливостей їх реалізації на вітчизняних теренах.

Виклад основного матеріалу. Основним орієнтиром для функціонування та розвитку кожної держави світу стає сьогодні дотримання прав і свобод людини. Цікаво, що перші уявлення щодо цих феноменів виникли ще у глибоку давнину, а спроби їх захисту апробовувалися в суспільних практиках багатьох цивілізацій упродовж століть.

У науці визнаним є факт, що із захисту прав людини починається історія права взагалі, оскільки такі права випливають з біологічної природи людини, як, наприклад, перше природне право кожного індивіда - право на життя, так само і права на свободу, гідність особи, особисту недоторканність, що були широковідомі ще на ранньому етапі розвитку людської спільноти [1, с. 27-28]. 
Зразком такого первинного нормотворення у сфері прав людини, що поширювалося, зокрема, й на українські землі, $є$ відома настанова феодального права “Литовський статут”, що затверджувалася в трьох редакціях 1529-му, 1566-му, 1588му роках. Свого часу Статут був одним із найбільш прогресивних нормативних документів у Свропі, оскільки його положення грунтувалися на ідеях рівності всіх людей перед законом незалежно від їх майнового і соціального стану й містили концепти особистої недоторканності, захисту прав людини (проте лише вільної шляхетної), особистої відповідальності людини перед законом [2, с. 102, 105].

Світовим орієнтиром у справі встановлення пріоритету основних прав і свобод людини вважаються затверджувані упродовж XIII - XVII ст. в Англії, нормативи щодо відносин між індивідом і державою. Серед них найдавнішим є “Велика хартія вольностей” (1215р.), згідно якої обмежувалася королівська влада й, відповідно, людям надавалися певні можливості щодо правового захисту проти деспотизму пануючої еліти. Законодавчим актом англійського парламенту "Habeas Corpus Act" (1679 р.) було визначено правила здійснення арешту і притягнення до суду, також зафіксовано право на захист людини від затримання без достатньої доказової бази. “Біллем про права" (1689р.) обмежувалася політична влада правлячої верхівки й заборонявся арешт людини без попереднього рішення суду.

Крім того, велику роль у встановленні прав і свобод людини відіграло затвердження у Франції “Декларації прав людини і громадянина” (1789 р.), у якій проголошувалися свобода та рівність, свобода віросповідання й власної думки, недоторканість права власності тощо.

Суттєвим кроком на шляху розуміння прав і свобод людини як вищої світової цінності стали й відомі нормативні документи, прийняті в Сполучених Шатах Америки. Це, зокрема, “Декларація незалежності” (1776 р.), що проголошує і гарантує право людини на життя, називає природними й невідчужуваними правами людини на свободу і прагнення до шастя. У перших десяти поправках до Конституції, відомих як "Білль про права" (1791р.), вперше зафіксовано перелік основних прав і свобод людини, що найбільше відповідають сучасному розумінню цих дефініцій.

Слід зазначити, що ще на початку XX ст. в країнах Європи було розроблено кілька проектів конституцій, що гарантували захист не лише класичних прав (політичні права, право на приватне життя), а й забезпечували соціально-економічні та культурні права людини, стимулюючи розвиток соціальної політики в гуманітарних сферах життя суспільства (освіта, громадянське здоров'я, сфера зайнятості тощо). До речі, прийнята в 1936 р. Конституція Радянського Союзу, до складу якого входила в той час і Україна, також містила певні державні гарантії щодо захисту, зокрема, права на працю (ст. 118), права на відпочинок (ст. 119), права на соціальне забезпечення (ст. 120), права на освіту (ст. 121).

У контексті вивчення історичних передумов і сучасного стану встановлення міжнародного порядку захисту прав і свобод людини, слід наголосити, що середина ХХ ст. виявилася переломним моментом у набутті проблемою захисту прав і свобод людини міжнародного резонансу й окресленні нормативних положень, що визнаються діючими і в сучасних законодавчих системах країн світу. Саме в цей час у контексті бурхливих подій XX століття виникла необхідність визначення універсальних правових основ міжнародного регулювання дій держав по відношенню до громадян задля забезпечення захисту прав і свобод кожної особистості. Одними 3 перших серед таких документів стали "Загальна декларація прав людини" Генеральної Асамблеї Організації об’єднаних націй (1948р.), ратифікована Україною 
через двадцять п'ять років після затвердження; “Конвенція про захист прав людини й основоположних свобод" Ради Свропи (1950р.), ратифікована нашою державою в 1997 р.; затверджені міжнародною спільнотою "Міжнародний пакт про громадянські та політичні права" й "Міжнародний пакт про економічні, соціальні й культурні права” (1966р.), ратифіковані Україною через три роки, та інші документи.

У зазначених нормативних документах на міжнародному рівні було вперше зафіксовано поняття про права i свободи людини загалом, що $є$ природними i залежать від їх нормативного закріплення лише гарантіями їх дотримання, але не своїм існуванням, а також про особисті права і свободи людини, що гарантуються державою.

Відзначимо, що в умовах стрімкого розгортання науково-технічного прогресу та розвитку ринкових відносин у другій половині ХХ ст. соціальні ризики щодо гарантій прав і свобод людини значно загострилися, актуалізуючи тим самим виникнення і функціонування правозахисних ініціатив, рухів, організацій як державних, так і громадських (політичні партії, профспілкові організації, різноманітні спілки тощо), що, у свою чергу, зумовило закріплення соціально-правових гарантій прав i свобод людини в суспільстві. Зокрема, діюча тоді на вітчизняних теренах Конституція Радянського Союзу (1977 р.) збагатилася низкою статей щодо захисту прав і свобод громадян. Так, стаття 42 гарантувала право на охорону здоров'я, стаття 44 - право на житло, згідно статті 46 люди мали право на користування досягненнями культури, стаття 47 забезпечувала право й свободу наукової, технічної та художньої творчості.

Активна інтеграція в законодавство України міжнародних правових стандартів щодо прав і свобод людини розпочалася 3 часів проголошення незалежності (1991 р.) та затвердження основного закону - Конституції України (1996 р.), який забезпечив право всіх категорій населення на захист прав і свобод, оскільки, згідно статті 1 Конституції, Україна є соціальною державою. За характеристикою дослідників (Д. Бєлов, Ю. Бисага, М. Данканич, М. Палінчак), у цьому нормативному документі вперше замість фрагментарного набору прав і свобод було визначено систему прав і свобод у всіх основних сферах, передбачено громадянські, політичні, економічні, соціальні й культурні права і свободи людини і громадянина [3, с. 23].

Сьогодні категорія “права і свободи людини” $\epsilon$ визнаною в Україні, як і в усьому світі нормативно-змістовою основою для побудови взаємовідносин між індивідом i державою, соціумом, за допомогою яких регламентуються межі свавільних дій і соціальних можливостей людини, встановлюються інституційні та нормативно-правові механізми обмежувальної взаємодії людини і суспільства.

Характеризуючи досліджувану дефініцію “права і свободи людини", слід виходити з того, що їі розглядають у контексті суміжних, а у деяких дослідженнях, навіть, синонімічних понять: "права і свободи особи", “особисті права і свободи", “права і свободи громадянина", що є уточнюючими по відношенню до базового поняття “права і свободи людини”, оскільки за загальними нормами міжнародного права невід'ємні права і свободи кожної людини, незалежно від того чи має вона громадянство, повинні поважитись будь-якою державою. Отже, права і свободи людини $\epsilon$ найбільш пріоритетним орієнтиром у законодавствах країн, права ж особи чи громадянина розкривають їх зміст відповідно до соціально-політичних умов, що складаються на теренах тієї чи іншої держави.

До того ж, часто, окрім поняття "права та свободи людини" використовують самостійні дефініції “права людини” та “свободи людини”, оскільки вони мають, 
хоча і споріднений, проте самостійний зміст. Права людини $є$ найвищим рівнем можливостей індивіда й вимог до соціуму, обумовлених самим фактом існування людини, детермінованим щаблем розвитку цивілізації й пов'язаним з тотальним i незаперечним визнанням пріоритетності потреб людини в суспільстві. Очевидно, що правам людини властива універсальність - приналежність усім людям в різних ситуаціях незалежно від обставин, соціального становища, мови, стану здоров'я тощо; такі права $є$ природними - будь-яка людина має права лише за фактом свого народження; права людини є невід'ємними, що визначає неможливість позбавлення чи відмови від цих прав. Разом із цим, зважаючи на наявність двох загально відомих теорій прав людини, слід зазначити, що лише в межах першої з них - природноправової - наголошується на об'єктивній природі й незалежності прав людини від держави, тоді як, з позицій другої - теорії позитивізму, права людини все ж $є$ детермінованими вимогами правової політики держави, законодавства й визначаються унормованими в державі практиками застосування права, роботи судів та інших органів влади [1, с. 45]. Враховуючи це, у науці і юридичній практиці пропонується розрізняти категорії “права громадянина", що регламентовані державним законодавством, i “права людини”, що мають природну основу i $\epsilon$ невід'ємними для всіх індивідів, $€$ позанаціональними, позатериторіальними, існують незалежно від закріплення в законодавчих актах держави, виступають об’єктом міжнародно-правового регулювання і захисту [4, с. 23-24].

Загалом, права людини завжди пов'язані 3 трьома важливими функціями. Насамперед, за характеристикою Т. Дашо, вони $\epsilon$ обмежувальними по відношенню до дій держави: права людини окреслюють межі індивідуальної та суспільної свободи особистості від деспотичного державного втручання [5, с. 115]. Крім того, права людини забезпечують суверенність індивіда - наявність власної приватної сфери, в яку не може втрутитися жодна влада, саме така приватна сфера, зазвичай, i позначається терміном "особисті права людини". Ще однією важливою рисою прав людини $€$ їх орієнтованість на захист індивіда та гарантованість законності протидії державі з боку людини з метою захисту власних прав.

На відміну від прав, що, як було з'ясовано вище, хоча й даються людині від народження, забезпечуються державою і передбачають наявність у суспільстві можливостей і механізмів щодо їх реалізації, свободи людини визначаються відсутністю бар'єрів й регламентувань у суспільстві щодо самопрояву індивіда. Втілення свободи пов'язано 3 активними діями людини, що не обмежуються 3 боку держави чи різних іiі інституцій, тому свободу можна визначити як можливість вчинити активну дію. Свободи, що належать людині, яка здатна до самостійних дій, не залежать від державного визнання та належать усім і назавжди. Це відсутність державного свавілля $з$ установленням легітимних, розумних та пропорційних обмежень держави в реалізації людиною своїх основних прав [5, с. 110]. За твердженням Ю. Бадалянца, термін "свобода" покликаний підкреслити більш широкі можливості для індивідуального вибору, не окреслюючи при цьому конкретного результату такого вибору. Тобто законодавець має на увазі вольову спрямованість і форму правової поведінки людини, а не той результат, який може бути досягнутий [6, с. 152].

Усі мають право на реалізацію природних й невід'ємних характеристик

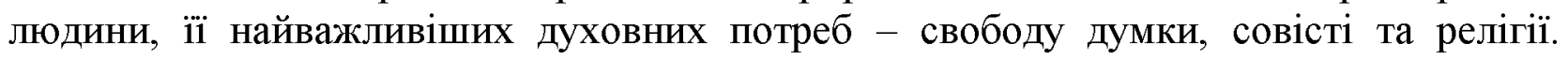
Індивід наділений цими свободами від народження й будь-яка інша людина, держава або іiі інституції не мають права заборонити користування ними. Свобода думки, совісті та релігії - є духовним грунтом, на якому зіждеться право людини вільно 
виражати власні переконання - свобода слова, без якої неможлива побудова демократичної держави, бо вона забезпечує один із дієвих механізмів регламентування громадою державної влади.

Сьогодні базові права і свободи людини закріплені в сучасних міжнародних $\mathrm{i}$ вітчизняних нормативно-правових документах, зокрема це, окрім вже зазначених свобод людини: право на життя, право на справедливе правосуддя, визнання правосуб'єктності, захист особистого і сімейного життя, недоторканність чи недискримінація, рівність, гідність; свободи від рабства, від тортур, пересування і вибору місця проживання.

Найбільш узагальнюючим у контексті дослідження прав і свобод людини $є$ наведений В. Кожаном перелік прав людини, що безпосередньо пов'язані 3 ii свободами: право на життя, право на гідність, право на свободу та право на особисту недоторканність. За твердженням автора, такий перелік прав логічно випливає із статті 3 Конституції України, яка проголосила людину найвищою соціальною цінністю, назвавши при цьому іiі основні невід'ємні якості, які їй належать: життя і здоров'я, честь і гідність, недоторканність та безпека [1, с. 42, 187]. Крім того, зазначені права закріплені Конституцією України в окремих статтях: право на життя (ст. 27), право на повагу гідності людини (ст. 28), право на невтручання в особисте і сімейне життя (ст. 32) тощо.

Серед природних прав людини, безпосередньо пов'язаних 3 iї свободами, базовим є право на життя. Згідно зі ст.6 "Міжнародного пакту про громадянські та політичні права", право на життя - це невід'ємне право кожної людини, що охороняється законом й жодна людина не може бути свавільно позбавлена життя. У Конституції України зазначається, що всі мають право на життя, а обов'язок держави - захищати життя людини. При цьому наголошується, що кожна людина має право захищати власне життя і здоров'я, життя і здоров'я інших людей від протиправних посягань (ст. 27). Тобто реалізація права на життя передбачає можливість такої поведінки людини, яка забезпечує захист власного життя та його недоторканності з боку інших людей, а також свободу вибору життєвого шляху.

У багатьох міжнародно-правових актах (Загальній декларації прав людини, Міжнародному пакті про економічні, соціальні й культурні права, Міжнародному пакті про громадянські й політичні права тощо) разом із правом на життя згадується гідність людини як пріоритет у захисті її прав і свобод. Право на повагу до людської гідності проголошується в Декларації про права розумово відсталих осіб (1971р.), Декларації про права осіб з інвалідністю (1975 р.), Декларації про раси та расові забобони (1978р.), Конвенції про права дитини (1989р.), Віденській декларації (1993 р.) тощо.

Право на повагу до людської гідності в багатьох нормативних документах поєднується 3 правом на свободу та особисту недоторканність, бо ці права мають спільну природу та споріднені механізми реалізації. На міжнародному рівні вищезазначені права закріплені Міжнародним пактом про громадянські та політичні права (1966 р.), Конвенцією про захист прав людини й основоположних свобод (1950 р.) та іншими законодавчими актами.

Право на повагу до людської гідності та право на свободу й особисту недоторканність нормативно закріплені й на національному рівні. Згідно зі статтею 3 Конституції України, найвищими соціальними цінностями, поряд із життям i здоров'ям, є честь та гідність, недоторканність та безпека. Стаття 29 Конституції закріплює право кожної людини на свободу й особисту недоторканність. Право на 
повагу й недоторканість гідності та честі проголошується й у статтях 297, 288 та 289 Цивільного кодексу. Окремі аспекти забезпечення права на свободу і права на особисту недоторканність містяться в Кримінальному кодексі України, Законах України "Про свободу пересування та вільний вибір місця проживання в Україні", “Про попередження насильства в сім'і”, "Про трансплантацію органів та інших анатомічних матеріалів людини”, “Основи законодавства України про охорону здоров'я" та ін.

Слід зазначити, що, не зважаючи на досить суттєві нормативно-правові гарантії держави у напрямі забезпечення прав і свобод людини в Україні, на жаль, сьогодні українська дійсність характеризується недостатньо високим рівнем правової і політичної культури, а нерідко й правовим нігілізмом, слабкістю демократичних традицій і навичок [7, с. 16]. Це зумовлює поширення в суспільстві дискримінації, як прямої, що позначає наявність відмінностей, виключення, обмеження або переваги, що заперечує або зменшує рівне здійснення прав людей у суспільстві, так і непрямої - ситуації, коли формально нейтральні правила, критерії або практика, що ставлять де-факто особу певної меншини в невигідне становище порівняно з іншими; а також утисків у вигляді небажаної для особи поведінки, метою або наслідком якої є приниження людської гідності за певними ознаками або створення напруженої, ворожої, образливої чи зневажливої атмосфери (Закон "Про засади запобігання та протидії дискримінації в Україні", ст. 1).

Зважаючи на необхідність посилення діяльності держави та окремих їі інституцій у напрямі захисту прав і свобод людини, однією з провідних стає правоохоронна функція держави - діяльність уповноважених державних органів з установлення й охорони правопорядку, забезпечення точного і повного виконання нормативних розпоряджень усіма громадянами, організаціями та державними органами. 3 метою реалізації цієї функції використовуються різні методи, серед яких правотворчості та правозастосування (діяльність компетентних органів шодо застосування заходів юридичної відповідальності). Д. Швець визначає правоохоронну функцію держави як комплексний напрям іiі діяльності, що об'єднує низку заходів (у тому числі примусових), заснованих на принципах справедливості й ефективності, що спрямовані на безконфліктну реалізацію прав, свобод і законних інтересів людини та громадянина, забезпечення соціальної злагоди, недопущення індивідуальних, колективних і масових порушень законності й правопорядку [8, с. 13-14].

Серед державних органів, яким доручено безпосередню реалізацію правоохоронної функції держави, суттєву роль відіграють органи внутрішніх справ. Саме на ці органи покладаються завдання щодо захисту прав i свобод громадян від протиправних посягань, забезпечення громадської безпеки [9, с. 37].

У діяльності органів внутрішніх справ, особливо у роботі поліції, порівняно 3 іншими правоохоронними структурами, вирішується найбільша кількість питань, пов'язаних із забезпеченням прав і свобод людини. Наголосимо, що зазначені правозахисні структури, на відміну від інших, безпосередньо перебувають у колі пильної уваги громадян, які з власного життєвого досвіду можуть судити про якість забезпечення державою правозахисних послуг. Від ефективності роботи поліції залежать й інші види діяльності органів внутрішніх справ й, у цілому, ефективність забезпечення прав і свобод громадян в різних сферах життєдіяльності суспільства.

Зазначимо, що в контексті реалізації правоохоронної функції держави, зокрема діяльності органів внутрішніх справ, важливим напрямом сьогодні стає правова просвіта й пропаганда верховенства права серед населення. На думку О. Бандурки, в 
умовах національно-культурного відродження України, створення правової держави i демократичного суспільства, інтеграції в європейське і світове співтовариство проблема правового виховання населення набуває найбільш суттєвого значення [10, c. 5]. За твердженням дослідника, вивчення правового виховання як складника загального виховного процесу не є новим напрямом досліджень у вітчизняній науці. Однак його проблеми стають особливо актуальними в період переходу від адміністративно-командної системи управління до побудови правової держави і громадянського суспільства. Тому наукове осмислення правовиховних явищ має здійснюватися крізь призму закономірностей, притаманних соціалізації особистості в цілому з урахуванням здобутків у сферах правознавства, філософії, педагогіки, соціології, соціальної психології, які вже тривалий час вивчають цей феномен [10, c. 7]. Відповідно можемо стверджувати, що правова просвіта й пропаганда верховенства права серед населення стають сьогодні актуальними шляхами забезпечення прав і свобод людини як пріоритету функціонування правової держави та їі інституцій.

Висновки. У цілому, проведений аналіз історичних передумов, сучасного міжнародного та вітчизняного нормативного законодавства дає підстави для висновку, що у світі загалом, та в Україні зокрема, відбулося поступове утвердження юридичних норм і правозахисних конструктів у галузі забезпечення прав і свобод людини, й, разом з цим, у країнах світу продовжується подальший розвиток i збагачення конкретних правозахисних моделей, модернізація і поступове поширення на всі соціальні верстви системи соціально-правового захисту, детермінованої 3 міжнародноправовими і внутрішньодержавними можливостями.

Права і свободи людини розглянуто як фундаментальні, невід'ємні та природні можливості кожної людини, які вона отримує від моменту народження і які забезпечують їі психофізичну і морально-особистісну індивідуальність. Виходячи 3 цього, наголосимо, що поглиблене розуміння сутності прав і свобод людини й громадянина забезпечує дотримання демократичного курсу розвитку держави, відбір таких форм i напрямів діяльності ïi правозахисних органів та інституцій, що забезпечують реалізацію принципу гарантування безпеки людини, який був закріплений у багатьох міжнародних документах, отримав свій подальший розвиток у нормах національного законодавства.

На нашу думку, подальша детальна розробка й упровадження змісту і форм правової просвіти й пропаганди верховенства права серед населення в діяльності правозахисних структур держави є перспективним напрямом подальшої роботи.

\section{Література}

1. Кожан В. В. Особисті права людини: загальнотеоретична характеристика : дис.... канд. юрид. наук : 12.00.01 / Володимир Віталійович Кожан ; Міністерство освіти і науки України, Національний університет “Львівська політехніка". - Львів, 2016. - 229 с.

2. Статути Великого князівства Литовського: У 3-х томах. - Том I. Статут Великого князівства Литовського 1529 року / За ред. С. Ківалова, П. Музиченка, А. Панькова. - Одеса: Юридична література, 2002. - 464 c.

3. Бисага Ю.М. Права людини / Ю.М.Бисага, М.М.Палінчак, Д.М.Бєлов. - Ужгород, 2003 - 189 с.

4. Негодченко О.В. Організаційно-правові засади діяльності органів внутрішніх справ щодо забезпечення прав і свобод людини : Монографія / О.В.Негодченко. - Д.: Вид-во Дніпропетр.ун-ту, 2003. - 448 с.

5. Дашо Т. Ю. Захист прав i свобод людини та громадянина на етапі формування громадянського суспільства / Т. Ю. Дашо // Вісник Національного університету “Львівська політехніка". Юридичні науки. - 2015. - № 813. - С. 108-118. 
6. Бадальянц Ю. С. Права человека : учеб. пособие / Ю. С. Бадальянц, Д. А. Ягофаров. - М.: Рязань : Поверенный, 2006. -519 с.

7. Коноваленко-Монзолевська Н. В. Свободи людини і можливості їхнього забезпечення державою: еволюція соціально-філософського дослідження / Н. В. Коноваленко-Монзолевська // Вісник Харківського національного педагогічного університету імені Г. С. Сковороди. Філософія. - 2013. - Вип. 41(2). - С. 16-27.

8. Швець Д.В. Захист прав і свобод людини та громадянина - пріоритет діяльності національної поліції України / Д.В.Швець // Правоохоронна функція держави: теоретико-методологічні та історико-правові проблеми : тези доп. круглого столу (Харків, 27 жовт. 2017 р.) / МВС України, Харків. нац. ун-т внутр. справ. - Харків, 2017. - С.13-15.

9. Криштанович М. Діяльність ОВС щодо захисту прав і свобод людини як важлива умова забезпечення національної безпеки України / М. Криштанович // Науковий вісник. - 2013. Вип. 12 “Демократичне врядування". - С. 34-38.

10. Правове виховання в сучасній Україні : монографія / А. П. Гетьман, Л. М. Герасіна, О. Г. Данильян та ін. ; за ред. В. Я. Тація, А. П. Гетьмана, О. Г. Данильяна. - Х. : Право, 2010. -368 с.

\section{References}

1. Kozhan V. V. Osobysti prava liudyny: zahalnoteoretychna kharakterystyka : dys.... kand. iuryd. nauk : 12.00.01 / Volodymyr Vitaliiovych Kozhan ; Ministerstvo osvity i nauky Ukrainy, Nationalnyi universytet "Lvivska politehnika". - Lviv, 2016. $-229 \mathrm{c}$

2. Statuty Velykoho kniazivstva Lytovskoho: U 3-kh tomakh. - Tom I. Statut Velykoho kniazivstva Lytovskoho 1529 roku / Za red. S. Kivalova, P. Muzychenka, A. Pankova. - Odesa: Iurydychna literatura, 2002. - $464 \mathrm{c}$.

3. Bysaha Iu. M. Prava liudyny / Iu. M. Bysaha, M. M. Palinchak, D. M. Byelov. - Uzhhorod, 2003. $189 \mathrm{c}$.

4. Nehodchenko O. V. Orhanizatsiino-pravovi zasady dialnosti orhaniv vnutrishnikh sprav shchodo zabezpechennia prav i svobod liudyny : Monohrafiia / O. V. Nehodchenko. - D.: Vyd-vo Dnipropetr. un-tu, 2003. $-448 \mathrm{c}$.

5. Dasho T. Iu. zakhyst prav i svobod liudyny ta hromadianyna na etapi formuvannia hromadianskoho suspilstva / T. Iu. Dasho // Visnyk Nationalnoho universytetu "Lvivska politehnika". Iurydychni nauky. - 2015. - № 813. - C. 108-118.

6. Badaliants Iu. S. Prava cheloveka : ucheb. posobie / Iu. S. Badaliants, D. A. Iahofarov. - M.: Riazan : Poverennui, 2006. $-519 \mathrm{c}$.

7. Konovalenko-Monzolevska N. V. Svobody liudyny i mozhlyvosti ikhnoho zabezpechennia derzhavoiu: evoliutsiia sotsialno-filosofskoho doslidzhennia / N. V. Konovalenko-Monzolevska // Visnyk Kharkivskoho natsionalnoho pedahohichnoho universytetu imeni H. S. Skovorody. Filosofiia. - 2013. - Vyp. 41 (2). - C. 16-27.

8. Chvets D. V. Zakhyst prav i svobod liudyny ta hromadianyna - priorytet diialnosti natsionalnoi politsii Ukrainy / D. V. Chvets // Pravookhoronna funktsiia derzhavy: teoretyko-metodolohichni ta istoryko-pravovi problemy : tezy dop. kruhloho stolu (Kharkiv, 27 zhovt. 2017 r.) / MVS Ukrainy, Kharkiv. nats. un-t vnutr. sprav. - Kharkiv, 2017. - C. 13-15.

9. Krychtanovych M. Diialnist OBS shchodo zakhystu prav i svobod liudyny iak vazhlyva umova zabezpechennia natsionalnoi bezpeky Ukrainy / M. Krychtanovych // Naukovyi visnyk. - 2013. Vyp. 12 "Demokratychne vriaduvannia". - C. 34-38.

10. Pravove vykhovannia v suchasnii Ukraini : monohrafiia / A. P. Hetman, L. M. Herasina, O. H. Danylian ta in. ; za red. V. Ia. Tatsia, A. P. Hetmana, O. H. Danyliana. - Kh. : Pravo, 2010. - 368 c.

Одержано статтю: 15.10.2019

Прийнято до друку: 11.11.2019 